\title{
The Watersplitting System of Photosynthesis I. A Postulated Model
}

\author{
G. RENGer \\ Max-Volmer-Institut, I. Institut für Physikalische Chemie, Technische Universität Berlin \\ (Z. Naturforsch. 25 b, 966-971 [1970] ; received 22 May 1970)
}

\begin{abstract}
For the natural donor of photosynthetic photosystem II an operational model is postulated. This model combines a definite structural pattern of two types of electron donors (octahedral arrangement of 6 secondary donors around a primary donor) with conformational state dependent electron transfer probability. It is shown that the model provides an explanation of many experimental data, especially the kinetics of the "priming" reactions of the watersplitting system can be quantitatively described.
\end{abstract}

In the electron transport pathway of photosynthesis electrons are transferred from $\mathrm{H}_{2} \mathrm{O}$ to $\mathrm{NADP}^{\oplus}$ (s. fig. 1). The oxidation of water is initiated by the excited $\mathrm{Chla}_{\mathrm{II}}{ }^{1,2}$. Within this process the elec-

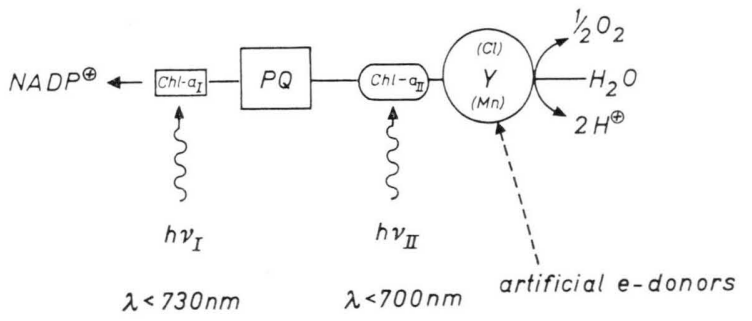

Fig. 1. Simplified electron transfer system in photosynthesis $^{8}$. NADP ${ }^{\oplus}=$ nicotinamide adenine dinucleotide phosphate, ChlaI $=$ chlorophyll aI, $\mathrm{PQ}=$ plastoquinone pool, ChlaII $=$ chlorophyll aII, $\mathrm{Y}=$ natural electron donor system for ChlaII,$(\mathrm{Cl})=$ chloride, $(\mathrm{Mn})=$ manganese.

* CCCP = carbonylcyanide-m-chlorophenylhydrazone.

1 G. Döring, H. H. STiehl, and H. T. Witt, Z. Naturforsch. 22 b, 639 [1967].

2 G. Döring, G. Renger, J. Vater, and H. T. Witt, Z. Naturforsch. 24 b, 22 [1969].

3 M. Klingenberg, A. Müller, P. Schmidt-Mende, and H. T. Witt, Nature [London] 194, 379 [1962].

${ }^{4}$ H. T. Witt, A. Müller, and B. Rumberg, Nature [London] 197, 987 [1963].

5 H. T. Witt, B. Rumberg, P. Schmidt-Mende, U. Siggel, B. Skerra, J. Vater, and J. Weikard, Angew. Chem. (Intern. Ed.) 4, 799 [1965].

${ }^{6}$ H. T. Witt, B. Skerra, and J. Vater, in: "Currents in Photosynthesis", Proc. 2nd Western-Europe Conf. on Photosynthesis, Woudschoten 1965. Donker-Publ., Rotterdam 1966, p. 273.

7 J. Vater, G. Renger, H. H. Stiehl, and H. T. Witt, Naturwissenschaften 55, 220 [1968].

${ }^{8}$ H. H. STIEhl and H. T. WitT, Z. Naturforsch. 24 b, 1588 [1969].

9 E. Kessler, Planta 49, 435 [1957].

10 P. Homann, Biochem. biophysic. Res. Commun. 33, 229 [1968]. trons are transferred from $\mathrm{H}_{2} \mathrm{O}$ via $\mathrm{Y}$ to plasto. quinone ${ }^{3-5}$. The electron transfer from $\mathrm{H}_{2} \mathrm{O}$ to $\mathrm{PQ}$ is limited by a reaction with a half life time $\tau_{1 / 2}=$ $6 \cdot 10^{-4} \mathrm{~s}^{6-8}$.

The enzyme system $\mathrm{Y}$ which mediates the oxidation of water is unknown.

It was found that manganese is an essential component of $\mathrm{Y}^{9-13}$. Further investigations led to the conclusion that chloride ${ }^{14-16}$ is necessary for the function of the water-splitting system, too. It is possible to substitute water as natural electron donor by artificial e-donors like ascorbat ${ }^{17}$ or paraphenylendiamine ${ }^{18}$ or diphenylcarbazide ${ }^{19}$. According to JоLIOT $^{20}$ a water cleavage occurs only on a double oxidized electron donor. In respect to the kinetic behaviour it was elucidated that a "priming" is necessary for the activation of the water splitting

11 B. Gerhard u. W. Wiesner, Biochem. biophysic. Res. Commun. 28, 958 [1967].

12 G. M. Cheniae and I. F. Martin, in: "Energy Conversion by the Photosynthetic Apparatus", Brookhaven, Sympos. Biol. 19, 406 [1966].

13 G. M. Cheniae and I. F. Martin, Biochim. biophysica Acta [Amsterdam] 153, 819 [1968].

14 R. L. Heath and G. Hind, Biochim. biophysica Acta [Am. sterdam] 172, 290 [1969].

15 S. IzawA, R. L. HeAth, and G. Hind, Biochim. biophysica Acta [Amsterdam] 190, 338 [1969].

16 R. L. Heath and G. Hind, Biochim. biophyica Acta [Amsterdam] 180, 414 [1969].

17 H. Böhme and A. Trebst, Biochim. biophysica Acta [Amsterdam] 180, 137 [1969].

18 T. Yamashita and W. L. Butler, in: "Comparative Biochemistry and Biophysics of Photosynthesis, ed. K. SHIBATA et al., University of Tokyo Press 1968, 179-185.

19 L. P. Vernon and E. R. Shaw, Biochem. biophysic. Res. Commun. 36, 878 [1969].

20 P. Joliot, Photochem. Photobiol. 8, 451 [1968]. 
system ${ }^{21-23}$. JoLIOT ${ }^{24}$ found that the "priming" of the watersplitting system is characterized by a specific kinetic behaviour.

The system $\mathrm{Y}$ is very sensitive against irreversible destruction by temperature ${ }^{25}, \mathrm{pH}^{26}$, UV-irradiation ${ }^{27}$ or tris-washing ${ }^{28}$.

Furthermore it was found that CCCP * influences directly the active states of $\mathrm{Y}$ produced by the "priming" reactions ${ }^{29,30}$. JOLIOT ${ }^{24}$ explained his results about the kinetics of the "priming" reactions by the assumption that each photochemical centre of system II includes two electron donors which are alternately connected with the electron acceptor. After each photoact a switch occurs with an efficiency of about 85 per cent.

In the presented paper firstly a model for the enzymatic complex $\mathrm{Y}$ is proposed on a molecular basis. Then it will be shown that the postulates of the model primarilly introduced axiomatically are compatible with the experimental data and that the kinetic behaviour of the model describes quantitatively the experimental results of JOLIOT ${ }^{24}$.

\section{The Model}

The following assumptions are made:

1. The natural donor of photosystem II is a highly ordered metalloprotein system, in the following named the donor cell.

2 . In the donorcell there are two different types of donors (s. fig. 2) :

A. the primary donor $\mathrm{D}$ which is directly connected with the photoreaction centre $\left(\mathrm{Chla}_{\Pi}\right)$ of system II. This arrangement is only a symbolized description indicating the fact that in a photoprocess at photosystem II an electron transfer from the primary electron donor $\mathrm{D}$ to the primary electron acceptor PQ is induced by $\mathrm{Chla}_{\mathrm{II}}$.

B. Six identical secondary donors $\mathrm{Mn}$ are arranged octahedrally around the primary donor D. Mn symbolizes one functional group of the metalloprotein system.

21 F. A. Allen and J. Franck, Arch. Biochem. Biophysics 58, 124 [1955].

22 P. Joliot, Biochim. biophysica Acta [Amsterdam] 102, 116 [1965].

23 P. Joliot, in: "Energy Conversion by the Photosynthetic Apparatus", Brookhaven, Sympos. Biol. 19, 418 [1966].

24 P. Joliot, G. Barbièri, and R. Chabaud, Photochem. Photobiol. 10, 309 [1969].

25 S. Katoh and A. SAN Pietro, Arch. Biochem. Biophysics 122, 144 [1967].

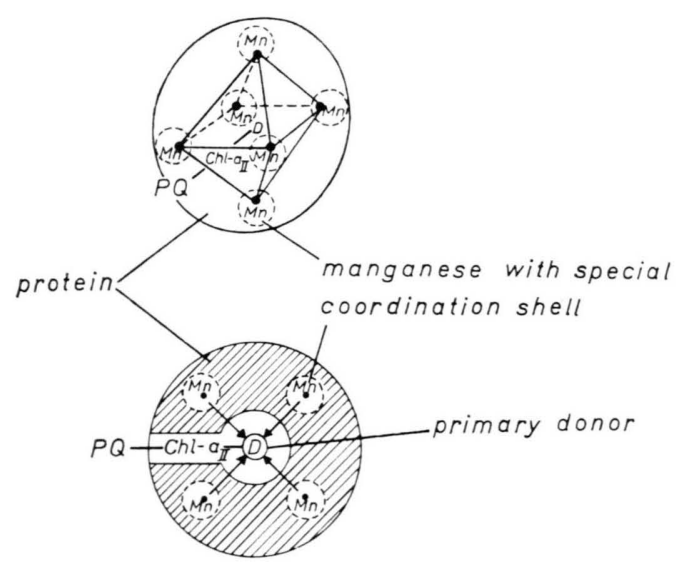

Fig. 2. Model of the donor cell. D = primary donor, ChlaII $=$ chlorophyll aII, $\mathrm{PQ}=$ plastoquinone, $\mathrm{Mn}=$ secondary donor (functional group), top: spacial figure, bottom: equatorial view, arrows indicate the electron flow from the secondary donors $\mathrm{Mn}$ to the primary donor D.

For the functional group behaviour the following assumptions are made:

a) The centre of the functional group is a manganese ion in a definite valence state (this state is not known).

b) The ligands around the central manganese ion are arranged in a special configuration. There exist two different stable conformational states, $\mathrm{C}_{1}$ and $\mathrm{C}_{2}$, and two labile conformational states $\mathrm{C}_{\text {lab }}^{\prime}$ and $\mathrm{C}_{\text {lab }}^{\prime \prime}$. (In fig. 3 conformation state $\mathrm{C}_{1}$ is indicated by broken circles, $\mathrm{C}_{2}$ by winded half circles and the two labile conformation states $\mathrm{C}_{\mathrm{lab}}^{\prime}$ and $\mathrm{C}^{\prime \prime}$ lab by half circles.)

3. Excitation of Chla II $_{\text {leads }}$ to the electron transfer from $\mathrm{D}$ to plastoquinone. The generated $\mathrm{D}^{\oplus}$ rapidly oxidizes one of the functional groups according to the electron transition probability determined by the conformational state of the ligand shell.

4. The electron transfer probability from $\mathrm{D}^{\oplus}$ to a functional group in the case of the conformational states $\mathrm{C}_{\text {lab }}^{\prime}$ or $\mathrm{C}_{\text {lab }}^{\prime \prime}$ or $\mathrm{C}_{2}$ is much higher than in the

${ }^{26}$ S. Katoh and A. San Pietro, Arch. Biochem. Biophysics 128, 378 [1968].

27 T. Yamashita and W. L. Butler, Plant Physiol. 43, 2037 [1968].

28 T. Yamashita and W. L. Butler, Plant Physiol. 43, 1978 [1968].

29 G. RENGER, Naturwissenschaften 56, 370 [1969].

$30 \mathrm{G}$. RENGER, in preparation. 
conformational state $\mathrm{C}_{1}$. That means: If a functional group has the conformational state $\mathrm{C}_{\text {lab }}^{\prime}$ or $\mathrm{C}^{\prime \prime}{ }_{\text {lab }}$ or $\mathrm{C}_{2}$ this group is oxidized in a photoreaction 6 via $\mathrm{D}$, whereas the functional groups in the conformational state $\mathrm{C}_{1}$ do not react. In the reduced state of a functional group only the conformational state $\mathrm{C}_{1}$ exists.

5. A conformation change is only possible by interaction of two oxidized functional groups located in the same donor cell. If the two interacting groups are neighbours the rapid transition $\mathrm{C}_{1} \rightarrow \mathrm{C}_{\text {lab }}^{\prime \prime}$ oc- 6 curs. If the two interacting groups are not neighbours only the rapid transition $\mathrm{C}_{1} \rightarrow \mathrm{C}_{\text {lab }}^{\prime}$ takes place. The conformational states $\mathrm{C}_{\text {lab }}^{\prime}$ or $\mathrm{C}^{\prime \prime}{ }_{\text {lab }}$ relax instantaneously to the $\mathrm{C}_{1}$ state at the end of the interaction caused by the reduction of one of the two oxidized functional groups.

If in the donor cell with two $\mathrm{Mn}^{\oplus}\left(\mathrm{C}^{\prime \prime}{ }_{\text {lab }}\right)$ functional groups and four $\operatorname{Mn}\left(\mathrm{C}_{1}\right)$-functional groups one of the $\mathrm{Mn}^{\oplus}\left(\mathrm{C}^{\prime \prime}\right.$ lab $)$-groups is oxidized to $\mathrm{Mn}^{2 \oplus}$ the instantaneous conformation transition $\mathrm{C}^{\prime \prime}{ }_{1 \mathrm{ab}} \rightarrow 5$ $\mathrm{C}_{2}$ occurs. The conformational state $\mathrm{C}_{2}$ relaxes slowly to the $\mathrm{C}_{1}$ state after the ending of the interaction.

6. A water cleavage is possible only on a double oxidized secondary donor $\mathrm{Mn}^{2 \oplus}$. The conformational state of the $\mathrm{Mn}^{2 \oplus}$-functional group does not influence the watersplitting reaction.

7. The system of the primary electron transfer from $\mathrm{D}$ to $\mathrm{PQ}$ has no influence on the redox and conformation behaviour of the secondary donor system. Furthermore there is no interaction between different donor cells in respect to the reactivity of these secondary donors.

From these postulates the following reaction scheme can be derived (fig. 3 ) .

In a dark adapted donor cell $\mathrm{E}_{\mathrm{i}}$ the first turnover induced by excitation of $\mathrm{Chla}_{\mathrm{II}}$ leads to the oxidation of one functional group $\mathrm{Mn}\left(\mathrm{C}_{1}\right)$ to $\mathrm{Mn}^{\oplus}\left(\mathrm{C}_{1}\right)$ (see eq. 1), via D. A donor cell with five $\operatorname{Mn}\left(C_{1}\right)$ and one $\mathrm{Mn}^{\oplus}\left(\mathrm{C}_{1}\right)$ functional groups is symbolized by $A_{1}$.

The second turnover now taking place in an $A_{1}$. donor cell causes the oxidation of one of the functional groups with the same probability (according to postulates 4 and 6) for the six functional groups. The probability amounts $\frac{1}{6}$ for the oxidation of the $\mathrm{Mn}^{\oplus}\left(\mathrm{C}_{1}\right)$-functional group to $\mathrm{Mn}^{2 \oplus}\left(\mathrm{C}_{1}\right)$ and $5_{6}^{5}$ for the oxidation of a $\mathrm{Mn}\left(\mathrm{C}_{1}\right)$-functional group to $\mathrm{Mn}^{\oplus}\left(\mathrm{C}_{1}\right)$ (see eq. 2 ). A donor cell with five $\operatorname{Mn}\left(\mathrm{C}_{1}\right)$ and one $\mathrm{Mn}^{2 \oplus}\left(\mathrm{C}_{1}\right.$ or $\left.\mathrm{C}_{2}\right)$ is symbolized by $\mathrm{Z}_{1}$, a
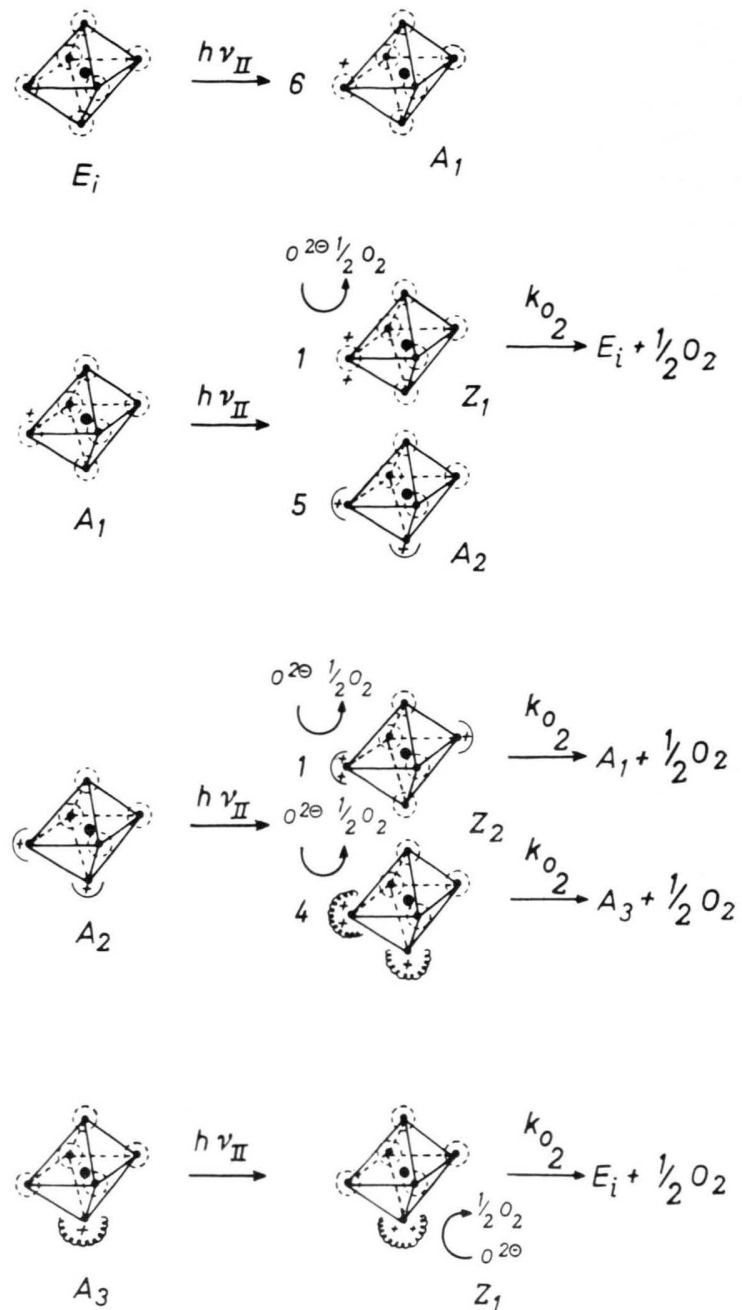

Fig. 3. Scheme for the reactions of the donor cell. The primary donor $\mathrm{D}$ is symbolized by a point in the centre of the octahedron, the secondary donors are indicated by points equipped with the following symbols for the conformational states: broken circles for $C_{1}$, half circles for $C^{\prime}$ lab and $C^{\prime \prime}$ lab, winded half circles for $C_{2}$. The relaxation reactions of the states $A_{1}$, $\mathrm{A}_{2}$ and $\mathrm{A}_{3}$ are not presented in this figure.

donor cell with two $\mathrm{Mn}^{\oplus}\left(\mathrm{C}_{\text {lab }}^{\prime}\right.$ or $\left.\mathrm{C}_{\text {lab }}^{\prime \prime}\right)$ and four $\operatorname{Mn}\left(\mathrm{C}_{1}\right)$ is indicated by $A_{2}$. According to postulate 7 the $\mathrm{Mn}^{2 \oplus}$-functional group oxidizes water thereby being reduced to $\operatorname{Mn}\left(C_{1}\right)$ (see eq. 5 ).

In the $A_{2}$-donorcell the probability is $\frac{4}{5}$ that the two $\mathrm{Mn}^{\oplus}$ groups are contiguous (therefore the rapid transition $\mathrm{C}_{1} \rightarrow \mathrm{C}_{\text {lab }}^{\prime \prime}$ takes place) and $\frac{1}{5}$ that the two $\mathrm{Mn}^{\oplus}$ groups are not contiguous (therefore the rapid transition $\mathrm{C}_{1} \rightarrow \mathrm{C}_{\text {lab }}^{\prime}$ occurs).

Because of the rapid conformation transitions in the $\mathrm{A}_{2}$-donor cell there are two $\mathrm{Mn}^{\oplus}\left(\mathrm{C}_{\text {lab }}^{\prime \prime}\right)$-functional groups and four $\mathrm{Mn}\left(\mathrm{C}_{1}\right)$-functional groups in 
the donor cell with a probability of $\frac{4}{5}$ and two $\mathrm{Mn}^{\odot}\left(\mathrm{C}_{\text {lab }}^{\prime}\right)$-functional groups and four $\mathrm{Mn}\left(\mathrm{C}_{1}\right)$ functional groups in the donor cell with a probability of $\frac{1}{5}$.

If a turnover in an $\mathrm{A}_{2}$-donor cell takes place, one of the two $\mathrm{Mn}^{\oplus}\left(\mathrm{C}_{\text {lab }}^{\prime}\right.$ or $\left.\mathrm{C}_{\text {lab }}^{\prime \prime}\right)$ is oxidized to $\mathrm{Mn}^{2 \odot}$ (postulate 4) producing a $Z_{2}$-donor cell which contains one $\mathrm{Mn}^{2}{ }^{\oplus}\left(\mathrm{C}_{2}\right.$ or $\left.\mathrm{C}_{\text {lab }}^{\prime}\right)$-functional group, one $\mathrm{Mn}^{\oplus}\left(\mathrm{C}_{2}\right.$ or $\left.\mathrm{C}_{\text {lab }}^{\prime}\right)$-functional group and four $\mathrm{Mn}$ $\left(\mathrm{C}_{1}\right)$ functional groups (see eq. 3 ). The $\mathrm{Mn}^{2}{ }^{\oplus}$-functional group cleavages water thereby being discharged to $\mathrm{Mn}\left(\mathrm{C}_{1}\right)$. Then the $\mathrm{Mn}^{2}{ }^{\oplus}-\mathrm{Mn}^{\oplus}\left(\mathrm{C}_{2}\right.$ or $\mathrm{C}_{\text {lab }}^{\prime}$ ) functional group interaction ceases and the rapid conformation transition $\mathrm{C}_{\text {lab }}^{\prime} \rightarrow \mathrm{C}_{1}$ occurs (postulate 6), whereas the $\mathrm{C}_{2}$-conformational state is relatively stable.

The $Z_{2}$-donor cell therefore reacts with a probability of $\frac{1}{5}$ to an $A_{1}$-donor cell and with a probability of $\frac{4}{5}$ to a donor cell $\mathrm{A}_{3}$, which contains one $\mathrm{Mn}^{\oplus}$ $\left(\mathrm{C}_{2}\right)$-functional group and five $\mathrm{Mn}\left(\mathrm{C}_{1}\right)$ functional groups (see eq. 6).

According to postulate 4 in an $A_{3}$-donor cell one turnover generates the $Z_{1}$-donor cell (see eq. 4 ). In the dark the donor cells in the states $A_{1}, A_{2}$ and $A_{3}$ slowly relax to $E_{i}$ (see eqs. $7,8,9$ ).

The seheme is summarized in fig. 4 .

$$
\begin{aligned}
& \mathrm{Ei} \stackrel{h \cdot v_{\mathrm{II}}}{\longrightarrow} \mathrm{A}_{1} . \\
& \mathrm{A}_{1} \stackrel{h \cdot v_{\mathrm{II}}}{\longrightarrow} \frac{5}{6} \mathrm{~A}_{2}+\frac{1}{6} \mathrm{Z}_{1} . \\
& \mathrm{A}_{2} \stackrel{h \cdot v_{\mathrm{II}}}{\longrightarrow} \mathrm{Z}_{2} . \\
& \mathrm{A}_{3} \stackrel{h \cdot v_{\mathrm{II}}}{\longrightarrow} \mathrm{Z}_{1} . \\
& \mathrm{Z}_{1} \stackrel{k_{\mathrm{O}}}{\longrightarrow} \mathrm{E}_{\mathrm{i}}+\frac{1}{2} \mathrm{O}_{2} . \\
& \mathrm{Z}_{2} \stackrel{k_{\mathrm{O}}}{\longrightarrow} \frac{4}{5} \mathrm{~A}_{3}+\frac{1}{5} \mathrm{~A}_{1}+\frac{1}{2} \mathrm{O}_{2} . \\
& \mathrm{A}_{1} \stackrel{k_{\mathrm{D}}^{(1)}}{\longrightarrow} \mathrm{E}_{\mathrm{i}} . \\
& \mathrm{A}_{2} \stackrel{k_{\mathrm{D}}^{(3)}}{\longrightarrow} \mathrm{A}_{1} \stackrel{k_{\mathrm{D}}^{(1)}}{\longrightarrow} \mathrm{E}_{\mathrm{i}} . \\
& \mathrm{A}_{3} \stackrel{k_{\mathrm{D}}^{(2)}}{\longrightarrow} \mathrm{A}_{1} \stackrel{k_{\mathrm{D}^{(1)}}}{\longrightarrow} \mathrm{E}_{\mathrm{i}} .
\end{aligned}
$$

Fig. 4. Scheme (1) - (9) .

$k_{\mathrm{D}}{ }^{(i)}$ are the relaxation constants with $i=1,2,3$. According to the results of JOLIOT ${ }^{20,23}$ these constants are of the order of $10^{-1} \mathrm{~s}^{-1}$ (assuming first order reactions).

$k_{02}$ is the pseudo first order rate constant for the dark reaction between the states $Z_{1}$ or $Z_{2}$ and $\mathrm{H}_{2} \mathrm{O}$ (the concentration of $\mathrm{H}_{2} \mathrm{O}$ is assumed to be constant).

Since the rate limiting step in the electron transport from $\mathrm{H}_{2} \mathrm{O}$ to $\mathrm{PQ}$ has a half life time of
$6 \cdot 10^{-4} \mathrm{~s}^{7,8}$ it follows that $k_{02} \geqq 1100 \mathrm{~s}^{-1}$. Further investigations of SINCLAIR ${ }^{31}$ led to the conclusion that $k_{\mathrm{O}_{2}} \geqq 5000 \mathrm{~s}^{-1}$.

The proposed model for the donor system of

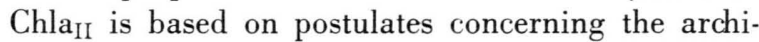
tecture of a hypothetical manganoprotein complex and on postulates regarding the relationship between conformational states and electron transfer probabilities. From these assumptions a reaction scheme is derived which implies a characteristic kinetical pattern of behaviour.

First it must be examined whether this reaction scheme describes the experimental results obtained by Joliot ${ }^{24}$ for the kinetic behaviour of the donor system Y.

Then it remains to show that the postulates stated axiomatically are compatible with the experimental facts so far known.

\section{a) Kinetics}

The experimental results of JOLIOT ${ }^{24}$ obtained by the excitation of photosynthesis with a sequence of short flashes $\left(\sim 10^{-5} \mathrm{~s}\right)$, which are separated from each other by a time $t_{\mathrm{d}}=300 \mathrm{~ms}$, are depicted in fig. 5 (open circles).

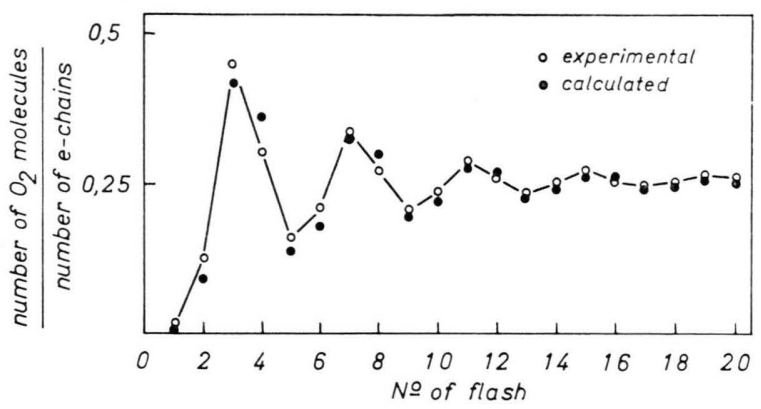

Fig. 5. Oxygen molecules per flash and per ChlaII, full circles: calculated values for excitation with short flashes (duration $\ll 6 \cdot 10^{-4} \mathrm{~s}$ ) and dark times between the flashes $t_{\mathrm{d}}$ in the range $150 \mathrm{~ms} \leqq t_{\mathrm{d}} \leqq 500 \mathrm{~ms}$; open circles: experimental results of JoLIOT ${ }^{24}$ (flash duration $\sim 10^{-5} \mathrm{~s}$, dark time $\left.t_{\mathrm{d}}=300 \mathrm{~ms}\right)$.

Because of the rate of the limiting step in the electron transport between $\mathrm{H}_{2} \mathrm{O}$ and $\mathrm{PQ}\left(\tau_{1 / 2}=\right.$ $6 \cdot 10^{-4} \mathrm{~s}^{7,8}$ ) excitation of photosynthesis with a short flash (duration $\ll 6 \cdot 10^{-4}$ s) only can lead to one turnover in Chla $\mathrm{II}$.

If in a sequence of short flashes additionally the time $t_{\mathrm{d}}$ between the flashes is long enough for com-

31 J. SinClair, Biochim. biophysica Acta [Amsterdam] 189, 60 [1969]. 
plete transport of electrons through the transport chain from $\mathrm{H}_{2} \mathrm{O}$ to the terminal acceptor $\left(t_{\mathrm{d}} \geqq 150\right.$ $\mathrm{ms}$ ) each flash of the sequence induces one (and only one) e-transfer through the chain.

If on the other hand the time $t_{\mathrm{d}}$ is short enough, the relaxation reactions (7) - (9) can be neglected. According to the results of JOLIOT ${ }^{20,}{ }^{23}$ this approximation is applicable for times $t_{\mathrm{d}} \leqq 500 \mathrm{~ms}$. Because the water cleavage must be faster than $6 \cdot 10^{-4} \mathrm{~s}$ the states $Z_{1}$ and $Z_{2}$ are completely converted (ep. (5) and (6)) at $t_{\mathrm{d}}=300 \mathrm{~ms}$. Therefore under the experimental conditions of JоLIOT ${ }^{24}$ the following simplified reaction scheme is valid:

$$
\begin{aligned}
& \mathrm{E}_{\mathrm{i}} \stackrel{h \cdot v_{\mathrm{II}}}{\longrightarrow} \mathrm{A}_{1} \cdot \\
& \mathrm{A}_{1} \stackrel{h \cdot v_{\mathrm{II}}}{\longrightarrow} \frac{5}{6} \mathrm{~A}_{2}+\frac{1}{6} \mathrm{E}_{\mathrm{i}}+\frac{1}{12} \mathrm{O}_{2} . \\
& \mathrm{A}_{2} \stackrel{h \cdot v_{\mathrm{II}}}{\rightarrow} \frac{4}{5} \mathrm{~A}_{3}+\frac{1}{5} \mathrm{~A}_{1}+\frac{1}{2} \mathrm{O}_{2} . \\
& \mathrm{A}_{3} \stackrel{h \cdot v_{\mathrm{II}}}{\longrightarrow} \mathrm{E}_{\mathrm{i}}+\frac{1}{2} \mathrm{O}_{2} .
\end{aligned}
$$

After a long dark time (a few minutes) all the donor cells are in the dark adapted state $\mathrm{E}_{\mathrm{i}}$. The excitation with the first flash leads to the reaction $E_{i} \rightarrow A_{1}$, no oxygen is produced. In the second flash $A_{1}$ is converted to $A_{2}$ and $E_{i}$ accompanied by the evolution of $\frac{1}{12} \mathrm{O}_{2}$ per donor cell [eq. (11)]. In the third flash $\frac{5}{6}$ of all of the donor cells transit from $A_{2}$ to $A_{3}$ and $A_{1}$ thereby evolving oxygen [eq. (12)] and $\frac{1}{6}$ of all of the donor cells are converted from state $E_{i}$ to $A_{1}$, no oxygen is produced. Therefore the third flash produces $\frac{\frac{5}{12}}{12} \mathrm{O}_{2}$ per donor cell.

Before the excitation with the fourth flash $\frac{1}{3}$ of the donorcells are in the state $A_{1}, \frac{2}{3}$ in the state $A_{3}$. The fourth flash leads to the transition into $\frac{5}{18} \mathrm{~A}_{2}$ and $\frac{13}{18} \quad \mathrm{E}_{\mathrm{i}}$-states [eq. (11) and (13)], $\frac{13}{36} \mathrm{O}_{2}$ are produced per donor cell. In the 5 th flash $\frac{5}{18}$ of the donor cells (state $\mathrm{A}_{2}$ ) are converted to $\frac{20}{90} \mathrm{~A}_{3}$, $\frac{5}{90} \quad \mathrm{~A}_{1}$ and $\frac{5}{36} \quad \mathrm{O}_{2}$ [eq. (12)], whereas $\frac{13}{18}$ of the donor cells (state $E_{i}$ ) are transferred to $\frac{13}{18} A_{1}$, no oxygen is produced [eq. (10) ].

32 G. M. Cheniae and I. F. Martin, Plant Physiol. 44, 351 [1969].

33 J. M. Anderson, N. K. Boardman and D. J. David, Biochem. biophysic. Res. Commun. 23, 874 [1964].

34 M. Itoh, K. Yamashita, T. Nishi, K. Konishi and K. Shibata, Biochim. biophysica Acta [Amsterdam] 180, 509 [1969].

35 K. Yamashita, M. IтоH, and K. Shibata, Biochim. biophysica Acta [Amsterdam] 189, 133 [1969].

36 D. Spencer and J. V. Possingham, Austra. J. Biol. Sci. 13, $441[1960]$.
Therefore in the 5 th flash $\frac{5}{36} \quad \mathrm{O}_{2}$ per donor cell are evolved.

In the same way it is possible to calculate the oxygen amount evolved by the 6th, 7 th, ..., nth flash. The obtained results are depicted in fig. 5 (full circles).

The calculated values are in good agreement with the experimental results of JoLIOT ${ }^{24}$. Therefore the postulated model covers the characteristic kinetical behaviour of the donor system of Chla $\mathrm{II}$.

\section{b) Structure}

The model postulates that at least six manganeses are bound per donor cell. CheniaE and MARTin ${ }^{32}$ found experimentally that $6-12$ manganese atoms are associated with each $\mathrm{O}_{2}$ evolving centre. Similar results were obtained by ANDERSON et al. ${ }^{33}$. About the nature of the primary donor the model is not restricted to any special substance. Therefore it could be possible that the primary donor also contains manganese. This assumption would explain the data of CHENIAE and MARTin ${ }^{32}$ who found two different types of manganese existing in system II. Furthermore tris-washing ${ }^{34,35}$ or heating lead to manganese-release. Experimental data of PosSINGHAM and SPENCER ${ }^{36}$ show that manganese is tightly bound to the watersplitting system. These experimental facts are in correspondence with the postulates concerning the role of manganese in the enzyme system $\mathrm{Y}$.

The model also assumes two different types of electron donors. The existence of at least two different electron donors can be derived from the results obtained with artificial electron donors for system II. It is obvious that the watersplitting system (in the presented model the system of secondary donors) can be completely destroyed, but the ability to transfer electrons from artificial electron donors via Chla II remains *.

\footnotetext{
* Note added in proof: Recently it was shown by VernoN and SHAw [Plant Physiol. 44, 1645 [1969]] that diphenylcarbazide only can donate electrons to photosystem II if the oxygen evolution system is inactivated. They concluded that in "intact chlorophasts photosystem II is not available to external agents and is 'covered up' by the enzymes responsible for oxygen evolution". This is in correspondence with the postulated model, where the primary electron donor $\mathrm{D}$ is covered up by the secondary donor manganoprotein system (the enzyme responsible for oxygen evolution).
} 
The effect of chloride ${ }^{14-16}$ on the water splitting system is explicable if one assumes that chloride is an essential ligand of the central manganese ion.

Furthermore it was pointed out by HeATH and HIND $^{36}$ that chloride- and manganese-deficiency causes very similar effects on electron transport. Artificial electron donors like hydroxylamine can bypass the manganese and chloride deficiency block. Hydroxylamine is oxidized directly by the primary electron donor D. Therefore no "priming" was observed in the oxidation of hydroxylamine ${ }^{38}$.

In contrast the effect of CCCP on the water splitting system ${ }^{29}$ is located at the secondary donors $\mathrm{Mn}$. It is assumed that CCCP accelerates the relaxation of the active states $A_{1}, A_{2}, A_{3}$ into the inactive state $\mathrm{E}_{\mathrm{i}}$ (see eq. $\left.7,8,9\right)^{30}$.

It was found that an electron pool of $\mathrm{PQ}$ exists on the reducing (acceptor) side of $\mathrm{Chla}_{\Pi}{ }^{39,40}$. According to the model an electron pool with the same capacity is postulated also for the oxidizing (donor) side of $\mathrm{Chla}_{\Pi}$. Under normal conditions this pool is not observable since the rate limiting step in the electron transport between the donor- and the acceptor-pool is located on the acceptor side of $\mathrm{Chla}_{\mathrm{II}}{ }^{7,8}$.

This prevents the accumulation of positive charges on the donor side of $\mathrm{Chla}_{\mathrm{II}}$. There is no experimental evidence for the existence of a donor pool. Although the fluorescence measurements of MurATA ${ }^{41}$ are a hint for the existence of the donor pool further investigations are necessary for the unequivocal evidence of this pool.

From structural informations about the photosynthetic apparatus it can be concluded that system

37 R. L. Heath and G. Hind, Biochim. biophysica Acta [Amsterdam] 189, 222 [1969].

28 P. Bennoun and A. Joliot, Biochim. biophysica Acta [Amsterdam] 189, 85 [1969].

39 B. Rumberg, P. Schmidt-Mende, J. Weikard, and H. T. WITT, in: "Photosynthetic Mechanisms in Green Plants", Publ. 1145, Nat. Acad. Sci. Natl. Res. Council, Publ. 1963, p. 18.

40 B. Rumberg, P. Schmidt-Mende, and H. T. Witt, Nature [London] 201, 466 [1964].

41 N. Murata, Biochim. biophysica Acta [Amsterdam] 162 , 106 [1968].

42 C. J. Arntzen, R. A. Dilley, and F. L. Crane, J. Cell Biol. 43, 16 [1969].

43 P. H. Homann, G. H. Schmidt, and H. Gaffron, in: "Comparative Biochem. and Biophys. of Photosynthesis", University of Tokyo Press 1968, p. 50.

44 T. E. Weier and A. A. Benson, Amer. J. Bot. 54, 389 [1967].
II is more complicated ${ }^{42-44}$ in the architecture than system I. This could be caused by the structure of Y.

The phenomena discussed here show that the postulates about the structural organisation and the existence of two different electron donors are compatible with the experimental facts.

\section{c) Conformational states}

Up to now for the existence of special conformational states in the secondary donors of the watersplitting system there is no experimental evidence. But it is known that in other metallic enzymes the properties (redox behaviour, absorption, ESR-activity) are determined by the structure of the ligand shell ${ }^{45-49}$.

Furthermore it is known that conformation transitions can be very fast $\left(10^{-7} \mathrm{~s}\right){ }^{50,51}$.

The electron transport probability is given by the shape and the height of the energy barrier ${ }^{52-54}$ between the primary donor and the functional groups. This is dependent on the geometry of the ligand shell.

The operational model described here is based on hypothetical assumptions. Unfortunately there is a complete lack of informations about the structure of $\mathrm{Y}$.

However, it is hoped that this model which covers the kinetic behaviour and which is compatible with the facts so far known will stimulate such structural studies.

I am indebted to Prof. H. T. WitT for valuable discussions and criticism.

45 J. A. Fee and Bo J. Malmström, Biochim. biophysica Acta [Amsterdam] 153, 299 [1968].

46 J. A. Fee, Bo G. Malmström, and T. Vänngard, in: "Biochemie des Sauerstoffs"; ed. B. Hess and HJ. Staudinger, Springer-Verlag, Berlin, Heidelberg, New York 1968, p. 29.

47 J. A. Fee, R. Malkin, B. G. Malmström, and T. VänNGARD, J. biol. Chemistry 244, 4200 [1969].

48 J. Monod, J. Weyman, and J. P. Changeux, in: "Theoretical Physics and Biology", ed. M. MARAIs, North Holland Publ. Comp., Amsterdam-London 1969, p. 267.

49 B. L. Vallee and R. J. P. Williams, Proc. nat. Acad. Sci. USA 59, 498 [1968].

50 M. Eigen, Quart. Rev. Biophysics 1, 3 [1969].

51 G. Schwarz, Ber. Bunsenges. physik. Chem. 68, 843 [1964].

52 F. Gutmann, Nature [London] 219, 1959 [1968].

53 L. Y. WEI, Bull. math. Biophysics 29, 411 [1967].

54 N. S. Hush, Trans. Faraday Soc. 57, 557 [1961]. 